\title{
LOS NAVARRO-OVEX: TRES GENERACIONES DE UNA FAMILIA MORISCA DE ELITE PERSEGUIDA POR LOS PODERES
}

\author{
M. ${ }^{a}$ del Carmen Ansón Calvo*
}

A Mikel Epalza $(\dagger), 30$ años de entrañable amistad.

La reconquista a los musulmanes de la parte aragonesa tuvo una fecha clave para las tierras zaragozanas, la del año 1118, año en el que Alfonso I "el Batallador" reconquista Zaragoza y, tras su éxito en la ciudad clave del Reino de Aragón, seguirán los conseguidos en otras ciudades importantes como Tarazona, Tudela, etc., y así paulatinamente se irán recuperando las tierras aragonesas al poder árabe. Alfonso I, consciente del problema demográfico-económico que suponía la expulsión de la población musulmana, inició una política inteligente, permitiendo que ésta permaneciera en los lugares que habitaba, pasando ahora de ser señores a vasallos de los nuevos señores, respetándoles sus usos y costumbres con una política de flexibilidad. Prueba de ello es que casi cuatro siglos después, el Fogage de vecindad de todos los lugares de Aragón, mandado hacer el año 1495 por Fernando II, recoge en él a los habitantes musulmanes con sus nombres y apellidos árabes.

Esta panorámica no era igual en otras partes de España, pues es de todos conocido que hasta el año 1492 existía un reino árabe en Granada, último reducto que será conquistado ese año por las huestes del matrimonio castellanoaragonés de Isabel I de Castilla y Fernando II de Aragón, consiguiendo con ello la unificación de sus reinos y la salida de unos "huéspedes" que habían permanecido más de siete centurias en suelo español. La marcha hacia el exilio del último rey árabe, Boabdil, y la salida de su corte y de sus súbditos fue "consensuada" por Fernando de Aragón, que demostró una vez más su talla política, tan elogiada en su época y en siglos venideros por escritores, políticos y estrategas militares de la importancia de Maquiavelo o Napoleón, practicando

\footnotetext{
* Universidad de Oviedo.
} 
una inteligente flexibilidad de gobierno y dejando que "los vencidos" siguieran practicando y desarrollando una cultura, unas costumbres, etc., propias, dentro o a la par de la sociedad cristiana vieja de su tiempo, como se recoge en las capitulaciones hechas tras la conquista, porque nada hay más penoso para un pueblo, para cualquier persona, individual o colectivamente, que despojarle de sus esencias, de su cultura y de sus principios y creencias religiosas. Pero esta permisividad política no tuvo una continuidad con sus sucesores y, tras su muerte, la regencia de Cisneros, hasta la llegada del nuevo rey, conllevó una nueva forma de gobierno para los vencidos. La situación de indefensión que les deparó la regencia de Cisneros, derivada del olvido del cumplimiento de las capitulaciones y acuerdos fernandinos, se plasma en aquel ejemplar memorial que presentó Núñez Muley en 1513, que en palabras de Barrios Aguilera "es un grito desgarrado, sobrecogedor, por la justificación de la identidad cultural de su pueblo" ${ }^{1}$. Este memorial será la bisagra clave de dos épocas: la del entendimiento de dos pueblos y la de la ruptura. Los árabes se verán desde entonces, cuando menos, como los "otros", los "extraños", los "ajenos" a la sociedad cristiana española, cuando más, como "peligrosos enemigos y traidores".

A la llegada a España en septiembre de 1517 del nieto del gran Fernando, el nuevo rey, Carlos I, ésta es la panorámica que verá: no hay unidad entre sus súbditos, sino disparidad y desunión. Lo cual, para un humanista borgoñón, con unas ideas políticas novedosas, que le llevaron, tras muchos esfuerzos, a conseguir un Estado Moderno, no era nada halagüeño. Todavía lo será menos el percatarse de su nula aceptación por sus nuevos súbditos, que le verán como un extranjero y un extraño gobernante, visión que le depararon las rebeliones comuneras de Castilla y agermanadas de la zona levantina, que acabaron con los triunfos reales. Con esta victoria parece que Carlos I de España y V de Alemania había conseguido la pacificación en sus tierras hispanas, pero no era sólo la pacificación lo que el futuro gran estadista, que llegaría a ser, deseaba alcanzar. El nuevo rey pertenecía a la generación de gobernantes que imponían una serie de condiciones y normativas en sus monarquías autoritarias, recogidas en su ideario carolino como fundamentales para alcanzar el Estado Moderno, ya iniciado por su regio abuelo materno, condiciones que se pueden resumir y plasmar en una sola palabra: unidad; la unidad de sus súbditos en religión, cultura, leyes, costumbres, etc., pero en esa unidad no participaban una parte de éstos, los musulmanes, que, con su propia idiosincrasia, implantaban la barrera que les separaba de los otros súbditos, los cristianos. Esta situación, la experiencia de los movimientos de rebeldía y separatismo de comuneros y agermanados y la importante presencia del poder turco, hermano en religión, costumbres, etc., de los musulmanes, derivó en la idea de llevar a la igualdad religiosa, de lengua, costumbres, etc., a todos sus súbditos, entre los que tenían

1. M. BARRIOS AgUILERA, «El reino de Granada en la época de Felipe II», en Felipe II (1527-1598), Madrid, 1998, vol. II, p. 63. 
un peso específico los musulmanes aragoneses y valencianos. Esta idea se hizo realidad en el invierno de 1525-1526, fecha que marcará un antes y un después en el reinado de Carlos I y en especial en una parte de sus súbditos: los musulmanes de los reinos de Aragón y de Valencia, a quienes se les ordenará dejar su religión, costumbres, lengua, cultura y convertirse "obligatoriamente" a la religión oficial, el cristianismo. Ellos formaran, junto a la vieja comunidad de los cristianos viejos, la de los cristianos nuevos o moriscos, nombres con los que se les designará a todos estos árabes, mahometanos de pensamiento y corazón, obligados por un decreto real a abrazar una nueva religión y, en apariencia, solo en apariencia, practicarla. Miles y miles de niños, adolescentes, jóvenes y ancianos tendrán que ir no a sus mezquitas, sino a los templos cristianos para dejar constancia de su apostasía a la religión que fielmente habían practicado ellos y sus antecesores, para abrazar la impuesta por los poderes: la Iglesia y el Estado. Entre esos miles de niños que, junto a sus mayores, se agrupaban para ser bautizados en febrero de 1526 en la religión cristiana se encontraban dos niños procedentes de tierras zaragozanas, dos niños que, según he deducido de distintos documentos, tenían entre 12 y 8 años de edad. La muchedumbre que allí se agolpaba, la actitud de sus padres y el mandato políticoeclesial y "familiar" de que debían de olvidar los nombres árabes de sus familiares y llamarlos con otros nuevos, así como que ellos mismos, tras su "obligado" bautismo, deberían de llamarse Miguel y Ana, es una imborrable vivencia en estos niños que ahora conoceremos como Miguel Navarro y Ana Ovex.

Miguel Navarro debía de tener unos 12 años cuando recibió el real mandato de olvidar sus antiguas oraciones y prácticas religiosas, de olvidar leyendas de los suyos y aprender otras nuevas. La documentación notarial e inquisitorial nos hace situar al niño Miguel Navarro en una familia acomodada, con importantes propiedades en el lugar de Borja y sus alrededores, acompañado de algunos hermanos, como Ana y un hermano bastardo llamado Jerónimo, o sus primos "Allovares" de Borja, a quienes veremos nombrados como beneficiarios en su último testamento. Su infancia y adolescencia transcurrieron entre el pueblo de Borja y la ciudad de Zaragoza, donde su familia poseía casas en la zona de la Morería de la parroquia de San Pablo y en la que pudieran poseerlas ya en el siglo XV, pues en el fogaje o censo de 1495 se cita a un Mahoma Navarro como habitante en la zona urbana de esta parroquia. Miguel Navarro, superadas las primeras etapas de su vida, adoptó la profesión de lencero, profesión que le permitió vivir muy holgadamente, a lo que sin duda contribuyeron también los sustanciosos emolumentos procedentes de sus muchos bienes familiares y los derivados de los que él mismo consiguió con sus negocios. Llegada la edad del matrimonio, calculo que alrededor de los 23 años, Miguel Navarro se desposó con una acaudalada morisca, Ana Ovex, que como él había tenido que aceptar una nueva religión cuando contaba unos 8 años. La joven Ana Ovex pertenecía a una muy rica familia aragonesa, con propiedades en la zona de Fuentes de Ebro, Gelsa y en las proximidades de Borja y Zaragoza, aunque debía de residir en Zaragoza, pues su padre fue enterrado en el ce- 
menterio del monasterio de Santa Engracia de esta ciudad. Su apellido paterno, Ovex, era frecuente en la minoría morisca aragonesa y la documentación da noticias de distintos Ovex procedentes de Almonacid, Gelsa y Zaragoza, todos ellos ricos, fieles al Islam y muy perseguidos por el Santo Oficio. Miguel Navarro y Ana Ovex debieron desposarse en Zaragoza y en esta ciudad fijaron su residencia en la zona de la Morería de la parroquia de San Pablo, ocupando una de las casas que poseían en la calle de la Cedacería y que después heredarían sus hijos Miguel y Ana y posteriormente sus nietos².

El matrimonio Navarro-Ovex fue prolífico, pues hasta el año 1563 nos consta que tenía seis hijos vivos, más otros que ya habían fallecido. De sus hijos vivos, cinco eran mujeres: Ana, María, Gracia, Guiomar y Francisca y un varón llamado Miguel, como su padre. La delimitación de señalar como año clave el de 1563 se debe a que en este año (30 de junio) el padre de familia hace su testamento ante el notario de Zaragoza Mateo Villanueva, en el que nombra como herederos a estos seis hijos y a su esposa ${ }^{3}$. En él hace constar que está doliente, pero de buen seso y poco fue el tiempo que debió de estar enfermo porque documentos hechos dos meses después citan a su esposa como viuda. En el testamento de Miguel Navarro se cita a sus dos hijas mayores, Ana y María, como ya casadas. Nuestra investigación nos lleva a conocer que éstas habían contraído matrimonio, respectivamente, con dos acaudalados y distinguidos moriscos, Juan Compañero y Alonso Almaguaque (A. Conte ${ }^{4}$ le apellida Alfanaqui, pero en nuestra documentación siempre consta como Almaguaque). Éstos procedían de tierras oscenses (Huesca o Argavieso), Juan Compañero, y de tierras próximas al Moncayo (Santa Cruz o Borja) Alonso de Almaguaque. Además, su hija Ana le había dado ya un nieto, Juanico, al que Miguel Navarro en su testamento deja, como a sus hijos solteros, "5 sueldos y sendas arrobas de tierra en los comunes de Zaragoza".

Interesa detenernos un poco en el testamento de este rico lencero morisco que, desde su matrimonio con Ana Ovex, si no antes, vivirá en la importante calle Cedacería de la Morería zaragozana de San Pablo y que fue uno de los protagonistas del bautismo forzoso del 14 de febrero de 1526. Si atendemos a la lectura del documento testamentario, podría decirse que "se adaptó" a su nueva religión y hasta cumplió con sus normas, pues en él pide que se le entierre en la sepultura de su suegro y al lado de la de sus hijos, sita en el cementerio del monasterio zaragozano de Santa Engracia y ruega a sus herederos que se celebren por su alma misa de difuntos y cabo de año, amén de legar la suma de 400 suel-

2. M.C. ANSÓN y P. GAY, «Las familias moriscas expulsadas de Zaragoza. Un análisis de sus bienes y propiedades», Actas del VII Simposium International l d'Etudes Morisques, Zaghouan, 1997, pp. 72-90.

3. A(rchivo).H(istórico).P(rotocolos).Z(aragoza).-Not(ario). Mateo Villanueva, Legajo 242, Año 1563.

4. A. Conte, Los moriscos de la ciudad de Huesca, Huesca, 2009, p. 344. 
dos para misas por su alma, una cantidad notable que señala, por una parte, la riqueza de este lencero, confirmada en documentación notarial, y por otra su ¿fervorosa? generosidad para con la Iglesia. El testamento de Miguel Navarro, que cumple las normas en cuanto al aspecto formal y jurídico del documento, es modélico porque en sus legados recuerda, además de a su mujer y a sus hijos, a varios miembros de su familia (a su hermana Ana le perdona cuanto le adeuda, menos 2.000 sueldos que devolverá a sus hijos, a su hermano bastardo Jerónimo lega una heredad en Borja, a su sobrino Juan de Momin 200 sueldos, a su tío Lope de Tarin y a sus primos "Allovares" de Borja 400 sueldos a cada uno), a distintos amigos lega bienes o perdona deudas, como a la viuda María Granada el alquiler de sus casas en Zaragoza, y tiene recuerdos pecuniarios para sus criados María de Ambel, Margarita, María Benami, Jerónimo Serrano y Lope de Denia. ¿Es un recuerdo de gratificación y ayuda a los menos favorecidos económicamente o el cumplimiento larvado de distintas suras coránicas? ${ }^{5}$.

La riqueza de este morisco se refleja en lo legado en su testamento: a su esposa: "por Capítulos Matrimoniales 80.000 sueldos jaqueses", más las joyas y vestidos que quiera, más un jarro de plata de su suegro, una cama de ropa y su paramento y las casas de su residencia en la calle Cedacería. A su hija mayor, Ana, lega dos portales de casas, valoradas en 14.000 sueldos, sitas en esta misma calle de la Cedacería (casas que encontraremos citadas en documentación y legados de esta familia y en el documento de venta de bienes de los moriscos, hecho tras su expulsión) ${ }^{6}$. A su segunda hija, María, residente en Borja, lega las casas en las que vive, más un corral, dos piezas de tierra y un palacio (edificio grande para guardar cosas) sito frente a lo que era la mezquita, estimado todo por valor de 16.000 sueldos; a su hija Gracia le da unas casas en Borja y una viña en Las Fuentes, por valor de 20.000 sueldos, más la ropa y paramento que su madre quisiera. A este respecto es interesante señalar que la búsqueda en documentación eclesiástica, notarial e inquisitorial permitió reconstruir la vida de los miembros de esta familia y el reparto que hace Miguel Navarro a sus tres hijas mayores ayudó y corroboró datos para esta reconstrucción. Ana y María, sus dos hijas mayores, estaban ya casadas cuando el padre hace su testamento y su tercera hija tenía una edad próxima a la que los moriscos consideraban apta para el matrimonio. Ante las diferentes opiniones sobre la pronta edad de matrimonio de las moriscas frente a la de las cristinas viejas y su elevado número de hijos, con la consecuente repercusión en su "explosiva demografía", tan citada por los panegiristas de la expulsión y cuestionada en investigaciones más recientes, lo deducido en esta investigación nos lleva a hacer algunas observaciones. En otros trabajos señalé que las moriscas se casaban a edades más tempranas que las cristianas viejas, quizá a los 17-18 años, y ello les permitía

5. El Corán (traducción de Julio Cortés), Barcelona, 2000. Suras 2, 4, 6, 8, 17, 59, 76, 89, 90, 93 y 107.

6. M.C. Ansón y P. GAY, op. cit., pp. 72-90. 
tener en promedio unos dos hijos más por matrimonio ${ }^{7}$. Esto parece que era lo habitual en "el estado llano" de esta minoría, pero, al estudiar minuciosamente a las moriscas pertenecientes a las familias de elite de la misma, los datos manejados me permiten deducir que muchas de éstas se casaban a los 15-16 años, mientras que los novios podían contar 7 o 10 años más que sus futuras mujeres y sus compromisos entre las dos familias se formalizaban, con harta frecuencia, entre uno y dos años antes de celebrarse la boda. Este es el caso de Ana y María Navarro Ovex, ya casadas alrededor de los 15 años, y por ello les dona casas en los lugares de su residencia matrimonial, Zaragoza y Borja. Su tercera hija, Gracia, todavía está soltera y, por ello, le lega su padre casas en Borja, que tomará al casarse en Zaragoza en 1566, también a los 16 años, y donde fijara su residencia, aunque seguirá poseyendo estas magníficas casas en Borja, que heredará su hijo Miguel Enrique Compañero. Como vemos, lo legado por Miguel Navarro a sus hijas mayores está claramente estipulado, pero no lo está tanto en el caso de sus hijas menores de edad, Guiomar y Francisca, a quienes deja 30.000 sueldos a cada una, "cuando se casaren y no antes", nombrando como tutores suyos a su esposa y a su hijo Miguel, que será su heredero universal, con la obligación de atenderlas y proveerles los cuidados médicos necesarios "como hijas de quien son". Esta expresión señala el estatus y consideración que Miguel Navarro tenía de sí mismo y que, a tenor de lo deducido de la documentación estudiada, se correspondía con la realidad social, cultural y económica de este destacado morisco y mucho más con la que llegaron a tener sus descendientes, calificados por escritores de la época como los reyezuelos moriscos aragoneses, y cuyos miembros enlazaron con las más notables familias moriscas, no sólo de Aragón sino de fuera de este reino, llegando a constituir lo que podría denominarse la elite o la aristocracia morisca aragonesa ${ }^{8}$.

El rico lencero Miguel Navarro deja en total, en dinero contante y sonante, 80.000 sueldos a su esposa, más el dinero adeudado por su hermana y por María Granada, y joyas, vestidos, ropa de cama, paramentos y una serie de locales, fincas rústicas e importantes casas en Borja y en la Morería zaragozana de la zona urbana de la parroquia de San Pablo9 . En este elenco de bienes no encontramos citados muebles, ni libros, pero sabemos que los tenía y parece que en buen número, en especial libros moriegos, pues precisamente el hallazgo de los que heredarían algunas de sus hijas, como Ana, será uno de los primeros motivos por los que serán perseguidos por la Inquisición ella, sus hermanas, su esposo y su

7. M.C. AnSÓN CALVO, «Demografía diferencial de la minoría morisca: una aportación a su estudio», Sharq Al-Andalus, 18, 2003-2007, pp. 39-72.

8. M.C. AnSÓN CALvo, «Diego de Rojas y Alonso Muley Merín de Fez: egregios esposos de Cándida Compañero», Sharq Al-Andalus, 18, 2003-2007, pp. 9-37.

9. M.C. ANSÓN CALVO, Demografía y Sociedad urbana en la Zaragoza del siglo XVII: un estudio con ordenadores, Zaragoza, 1977; Id., "Callejero de la Parroquia de San Pablo de Zaragoza en el siglo XVII», Cuadernos Zaragoza, 19, 1979; Id., «Plano más probable de Zaragoza en el siglo XVII», Actas del X Congreso de Historia de la Corona de Aragón, Zaragoza, 1984, pp. 1-13. 
cuñada. Podría decirse que con Miguel Navarro y sus libros prohibidos comienza "la persecución inquisitorial de esta familia", persecución que, como veremos, va a arrastrar a las tres generaciones que les sucedieron y entre las que encontraremos algunas magníficas lectoras. A este respecto, es curioso comentar que el testamento de Miguel Navarro lo aprueba su esposa pero no lo firma porque no sabía firmar, según hace constar el notario, pero él sí que sabía y lo firma. Poco después de plasmar sus últimas voluntades debió de morir Miguel Navarro, pues tan sólo un año después (30/X/1564) hará testamento su esposa ante el notario zaragozano Jerónimo Arnedo, citándosele como viuda ${ }^{10}$.

La esposa de Miguel Navarro, Ana Ovex, en su último testamento manifiesta que está enferma y por ello lo hace. Su primer deseo es ser enterrada también en el monasterio de Santa Engracia, al lado de la sepultura de su marido, y que se celebren por su alma misas por valor de 600 sueldos. Tras esto, comienza la enumeración de las dejas a sus hijos, Ana, María, Gracia y Miguel Navarro, es decir, cuatro hijos, frente a los seis que se citan en el testamento de su esposo. La "desaparición” de sus dos hijas pequeñas, Guiomar y Francisca, y la enfermedad y cercana muerte de Ana Ovex, tan próxima a la de su marido, me hizo pensar en algún acontecer puntual que pudo incidir en la súbita desaparición de tres miembros de la familia en tan corto espacio de tiempo. La respuesta creo que viene dada por la agresiva peste que entre los años 1563-1565 sufrió Aragón y de forma más destacada la ciudad de Zaragoza en el año 1564. Juan Tomas Porcell, el ilustre médico siciliano-aragonés, explicó magistralmente el desarrollo de la enfermedad pestilente que se cebó dramáticamente con la población zaragozana. Él mismo nos dice que trató a 800 enfermos en el Hospital de Gracia y explica el desarrollo de la enfermedad, y medios de curación, dejando a la posterioridad una obra inmortal ${ }^{11}$. Así pues, creo que la familia Navarro-Ovex disminuyó de una forma dramática y fulminante, pues perdió a cuatro de sus miembros, los padres y sus dos hijas más pequeñas, y de ellos con seguridad tres, o quizá todos, víctimas de la gravísima peste del bienio 1563-1565. La preocupación y mandato que recoge el testamento paterno, instando a los tutores de sus hijas pequeñas a que se les procuren cuidados médicos y las medicinas que necesiten, parecen también indicar que el padre conocía ya que sus hijas estaban enfermas y necesitaban estos cuidados.

Ana Ovex comienza el apartado testamentario de sus legados dejando, como parece era costumbre, 5 sueldos a cada uno de sus cuatro hijos vivos, Ana, María, Gracia y Miguel. Tras esta disposición hace la enumeración de dejas a distintas personas, algunas de ellas también beneficiarias en el testamento de su marido, como miembros de la familia Allovar (a Beatriz y Jerónima 300 sueldos) y a Lope Tarin 300 sueldos. Después recuerda a varias viudas, como

10. A.H.P.Z., Not. Jerónimo Arnedo. Leg. 4090, año 1564.

11. J.T. PORCELL, Información y curación de la peste de Zaragoza y presentación contra la peste en general, Zaragoza, por Vda. de Najera, 1565. 
la de Allovar y la de Cotina, a quienes deja 100 sueldos y una saya con cuerpo y mangas y a sus primos Ovex de Albeta 200 sueldos, a Clemente Ovex de Gelsa 400, pero dando de éstos 100 a su criada de Gelsa. Más generosa es con su criada, María, que vive en Bureta, a la que lega 400 sueldos. Es decir, al igual que su esposo, recuerda en su último legado a familiares y personas no acaudaladas o que trabajaban en su hogar.

Los legados de sus hijos provenientes del testamento de su padre se verán ahora aumentados con lo que su madre les deja. Nombra heredero universal a su hijo Miguel Navarro, pero con la condición de que "de a cada una de sus hermanas casas y heredades por valor de 16.000 sueldos, con tasadores puestos por él y por ellas", cantidades que hace constar proceden de los 80.000 sueldos jaqueses que su marido le dejó de gracia especial en su testamento "en paga de lo que podían alcanzar los bienes comunes" de ambos. En este caso, como en otros muchos estudiados, se demuestra claramente "la preferencia o beneficio" a favor de los varones, pues lo recibido por cada hija es sólo el $20 \%$ de la cantidad legada, frente al 40 de lo recibido por el hijo varón. A este respecto, pienso de nuevo que los preceptos coránicos no los habían olvidado aquellos niños bautizados en su "otra" religión y cumplieron el mandato coránico que dice "Dios os ordena lo siguiente en lo que toca a vuestros hijos: que la porción del varón equivalga a la de dos hembras"12. Por otra parte, las peticiones recogidas en los testamentos de Miguel Navarro y de Ana Ovex sobre misas y actos fúnebres podrían llevarnos a deducir que aquellos niños bautizados en la religión oficial la aceptaron y cumplieron los preceptos religiosos de la misma, pero el estudio de la trayectoria de sus vidas y las de sus descendientes, que comprenden cuatro generaciones hasta el momento de la expulsión de la minoría morisca, es decir, la del matrimonio Navarro-Ovex, las de sus hijos, las de sus nietos y las de sus bisnietos, nos conducen a otras conclusiones diferentes. Las noticias que sobre ellos tenemos parecen ser contradictorias en algunos momentos de sus vidas; se bautizan, casan y mueren cumpliendo las normas de la religión cristiana y sus testamentos presentan cuestiones formales diplomáticas y paleográficas de la época y hasta comienzan, como los de cristianos viejos, con las estereotipadas fórmulas de los preámbulos, pidiendo a Dios que los acoja en su seno, etc. (rara vez se invoca a la Virgen), pero las acusaciones recogidas en las Relaciones de Causas Inquisitoriales, las declaraciones de criados, familiares, testigos y "chivatos" del Santo Oficio, no siempre fiables (Gil Pérez, Luis Moreno, etc.), presentan a los miembros de la familia Navarro-Ovex y a sus amigos y criados o sirvientes como fieles seguidores de las costumbres de "moros", poseedores de libros moriegos y muy cumplidores de los preceptos coránicos. Es verdad que la persecución inquisitorial en sí, de forma declarada, comienza con sus hijos y no con los progenitores, pero también es verdad que éstos fueron, en parte, el origen de ella, pues fueron quienes sembraron la simiente de sus creencias, de sus costumbres y de sus lecturas y que, aunque no

12. Corán, suras 4,11 y 176 . 
he encontrado noticias sobre persecución a Miguel y Ana, sabemos que eran personas muy destacadas por su riqueza y su importancia social y religiosa dentro de la comunidad morisca aragonesa y de ello eran conocedores los representantes de la Iglesia y del Estado. No puede ser casualidad que en una de las primeras "visitas" inquisitoriales a la casa de su hija mayor, Ana Navarro, ya casada con el líder morisco Juan Compañero, se le "descubra" y requise un altísimo número de coranes y libros moriegos escondidos en el gallinero de su casa y de ellos se diga que "eran propiedad de su padre, Miguel Navarro", y también otros libros similares y del mismo propietario se recogen en los registros hechos en casa de su cuñada Cándida Compañero. Además, a lo largo del estudio de las tristes y complicadas vidas de sus hijos, nietos y bisnietos, vamos a ver la reiterada presencia de castigos inquisitoriales por sus prácticas religiosas mahometanas, enseñadas por las mujeres de la familia a sus hijos y a sus criados, reunidos en veladas nocturnas en las que ellas leían partes del Corán y todos juntos practicaban ceremonias y oraciones de la religión mahometana, como señalaremos más adelante. Es decir, todo conduce a pensar que aquel bautismo forzoso a la religión cristiana en el invierno de 1526 no fue para los niños Miguel Navarro y Ana Ovex un cambio "definitivo" en sus creencias, en sus costumbres, ni en sus vidas y lo que guardaron en su pensamiento y en su corazón fueron las enseñadas por sus mayores y que ellos procuraron transmitir a sus hijos y éstos a las generaciones sucesivas, lo que les deparó duros castigos inquisitoriales y la muerte. Tras fallecer en el bienio 1563-1564 los progenitores de la familia Navarro-Ovex, con ellos desaparece el primer núcleo familiar que nos ocupa o los fundadores de las tres generaciones cuyos tristes caminos seguiremos en esta aportación.

Hasta el momento de su muerte parece que Miguel Navarro y Ana Ovex gozaron de una consideración y un estatus muy notables en la comunidad morisca aragonesa y prueba de ello es que sus tres hijas contraen matrimonio con miembros de las familias moriscas más acaudaladas y más respetadas. Ellos mismos participaron en el matrimonio de su hija mayor, Ana, en 1555, cuando debía contar unos 16 años, con Juan Compañero Zafar, miembro de dos poderosísimas y acaudaladas familias oscenses, los Compañero y los Zafar; y en el de su segunda hija, María, con el honorable Alonso de Almaguaque, un rico y notable morisco con raíces en tierras de Borja y en el pueblecito cercano al Moncayo de Santa Cruz, y su hija pequeña, Gracia, aproximadamente cuando contaba 16 años, celebrará su misa nupcial en la zaragozana parroquia de San Pablo, el 15 de julio de 1566 con el hermano de su cuñado, con Enrique Compañero. Doble enlace de dos hermanas con dos hermanos no inhabitual entre las familias ricas y poderosas, tanto en la comunidad morisca como en la de cristianos viejos, asegurándose con ello poder económico y social y la conservación de patrimonios y estatus ${ }^{13}$. Así pues, parecía que en la cuestión de los enlaces

13. A(rchivo). P(arroquial). (S. P(ablo). Z(aragoza). Libro I de Casados. 
de sus hijas todo estaba, como se decía en la época, "atado y bien atado", máxime si tenemos en cuenta que su hija mayor les ha dado ya en 1561 un nieto, Juanico, a quien su abuelo beneficia también en su legado testamentario. Todo parecía sonreír a esta familia de la altísima "burguesía" de mercaderes y propietarios, cuyas hijas habían enlazado matrimonialmente con lo más preclaro de su sociedad y con quienes llegarían a ocupar los lugares más altos en riqueza y en consideración social, pero no todo fueron venturas para sus descendientes. Afortunadamente para el matrimonio Navarro-Ovex, ellos no pudieron imaginar las tristes vidas que a sus hijas, sus nietos y a sus bisnietos les iba a deparar el Estado y la Inquisición de "su país".

La mayor de las hijas, Ana, y su marido, Juan Compañero, en los primeros años de su matrimonio, alternaron sus estancias entre la ciudad de Zaragoza y tierras oscenses, donde Juan tenía importantes negocios y valiosas propiedades (Sobrepuerto, Aldaguesca, Argavieso y en especial Huesca) y donde nació y fue bautizado su hijo Juanico en 1561, pero desde 1566 fijaron su residencia en Zaragoza. En esta ciudad, en la zona de la Morería de la parroquia de San Pablo, tenía Ana su casa en la calle del Peco (Cedacería), casa que debió de ser amplia e importante, a juzgar por el muy alto precio dado en la valoración de los bienes de moriscos tras su expulsión. Próxima a ésta, en la misma calle, vivirán sus hermanos Gracia Navarro y Enrique Compañero, casa heredada también por Gracia, y próxima a éstas la que desde 1567 ocupara el matrimonio de su cuñada Cándida Compañero y Jerónimo Zafar. Estos tres matrimonios demuestran, una vez más, la frecuente endogamia sanguínea o política, practicada por la élite morisca aragonesa.

Todo parece indicar que el clan de los Compañero vivía de una forma un tanto idílica en Zaragoza, dedicados los hombres a sus múltiples y beneficiosos negocios, explotando de forma magistral sus bienes y los que arrendaban de otros poderosos cristianos viejos y hasta de importantes nobles, negocios y conexiones que salían fuera de nuestras fronteras y que les permitieron extender sus redes comerciales, sociales y de poder a Constantinopla, Francia, Argel y otras partes del norte de África. Las mujeres ocupaban un lugar destacado en sus familias, dedicadas al cuidado de sus hijos y de sus hogares, habitados por un buen número de sirvientes y en los que eran frecuentes las reuniones sociales y familiares, reuniones que no siempre fueron bien vistas por los poderes de la Iglesia y del Estado, porque las consideraban motivo de prácticas religiosas moras y de lecturas e instrucciones coránicas y que, como veremos, fueron en buena parte causa de persecución, cárcel y hasta de relajación y muerte de los miembros de estas familias, en especial de las mujeres. A ellas el Santo Oficio culpaba de ser las fieles transmisoras de esas prácticas y las consideraba "más valientes y peligrosas que sus maridos, quienes no se atreven a contradecirlas ni a beber vino por el miedo a ellas". La realidad es que el estudio minucioso de las Relaciones de Causas referentes a la rama femenina de los descendientes de Miguel Navarro y Ana Ovex hace deducir que esto era así, pues su valentía y comportamiento fueron siempre ejemplares. 
Volviendo al matrimonio de la primera hija de los Navarro-Ovex, Ana Navarro con Juan Compañero, parece que su idílica vida de acaudalados y reconocidos moriscos y con un hijo se truncó a mediados de la década de 1570. En estos años, tras la durísima rebelión de los moriscos de La Alpujarra y los problemas de política exterior, agudizados a lo largo del reinado de Felipe II de Castilla, I de Aragón, el temor a rebeliones, complots y levantamientos de la minoría morisca, con ayuda de los poderes enemigos del Estado español, fueron aumentando paulatinamente, a la vez que los castigos a los posibles autores o colaboradores de ellos y en esta progresiva intensificación de suspicacias y castigos veremos la mano "amiga" del Estado, el Santo Oficio. La Inquisición aragonesa, a pesar de ser una institución no reconocida por nuestros Fueros, cumplió también sus objetivos pues, según nuestras investigaciones, el tribunal zaragozano fue el más duro de los tribunales inquisitoriales, llevando a la cárcel y a las galeras un alto número de súbditos moriscos, en especial a los considerados "los más ricos, los más importantes y los líderes de su comunidad", como recogen sus procesos. Por ello, no va a extrañarnos que la vida de quienes formaban el clan de los Compañero-Navarro y familiares colaterales comience desde mediados de 1575 a estar en el punto de mira de los poderes y que la intervención del Santo Oficio sea cada vez más agresiva ${ }^{14}$.

En 1577 las visitas del morisco Izquierdo, de Juce Duarte y de otros "amigos" del poder turco y las cartas de éste leídas a los moriscos aragoneses por sus líderes, entre los que se cita a Juan Compañero por pueblos oscenses, pondrá a éste en el punto de mira de la Inquisición, por considerarlo "el más importante de los moriscos aragoneses y líder de los mismos" y así será apresado, tras haber estado en Huesca, según él a comprar unos alerces protectores y según el Estado a leer las cartas del turco y preparar un levantamiento. La situación se agravó con el edicto real que prohibía llevar armas a los moriscos y sobre ello hubo reuniones en diferentes lugares próximos al Moncayo, en especial en algunos propiedad del duque de Villahermosa, como Torrellas, de donde era líder su justicia, el destacado morisco Gaspar Zaydejos ${ }^{15}$ y en otros lugares importantes, como Bureta de Lope de Francia o como Borja, donde parece que acaudillaba el malestar de los moriscos el notable Alonso de Almaguaque, a la sazón cuñado de Juan Compañero por estar casado con la hermana de su mujer, María Navarro. Su propósito de "hacerse fuertes en Mesones o en Torrellas" antes que entregar las armas era ya un indicio de cómo estaba la situación entre los moriscos y de la prevención del Estado ante ellos y sus líderes. En mayo de 1578, debido a las acusaciones como instigador y líder de los posibles levantamientos y de cumplir los preceptos coránicos, es apresado Juan

14. M.C. ANSÓN CALVO, «Poder social, poder económico y persecución: variables significativas en algunos procesos inquisitoriales aragoneses», Disidencias y Exilios en la España Moderna, Alicante, 1997, vol. II, pp. 193-212.

15. Id., «El líder morisco de Torrellas», Actas del Simposio Internacional de Mudejarismo (Mudéjares y Moriscos. Cambios sociales y culturales), Teruel, 2004, pp. 577-599. 
Compañero. En sus declaraciones reconoció haber ayunado el Ramadán durante diez años, pero la Inquisición consideró que "había estado diminuto en sus declaraciones sobre su amistad con Duarte y las cartas del turco" y "dado que entendemos que es el caudillo principal de su nación en este Reino debe recluirse en la cárcel", así dice una carta escrita en la cárcel inquisitorial zaragozana de la Aljafería el 30 de junio de 1578, año en que aumentan los comentarios sobre la enemistad de los moriscos hacia el Estado, tanto que en otra carta escrita también en la Aljafería (17/X/1578) se dice que éstos "corrieron toros celebrando el desastre de nuestra Armada con Portugal" y se habla de un levantamiento con la ayuda de D. Antonio de Portugal y del príncipe de Orange.

En 1580, declaraciones de algunas moriscas, como María Belbis y María Compas, señalan que Juan Compañero, su mujer, las hermanas de ésta y su propia hermana, Cándida Compañero, han "xaedado" a moriscas, leen y cumplen las reglas del Corán, sus familias se reunían y rezaban azoras moriegas y una de las hermanas Navarro, Gracia, leía en las veladas nocturnas partes del Corán y de otros libros moriegos y lo hacía "mejor que un alfaquí". Estas declaraciones y otras noticias motivan el registro inquisitorial, en las casas de Juan Compañero y Ana Navarro, en las de las hermanas de ésta, María y Gracia, y en la de su cuñada, Cándida Compañero Zafar. El hallazgo en un gallinero y en una obra entre paredes de muchos libros moriegos (hasta 30 coranes), que se dice procedían de la herencia de Miguel Navarro, motivará el apresamiento de todos ellos y posteriormente ser juzgados en un Auto de Fe. Es el principio del fin de la apacible vida de este grupo familiar. Realmente la situación era preocupante desde 1577-1578, pues ya en el Auto de Fe del 16 de noviembre de 1577 tomó parte Ana Navarro y tras sus declaraciones, que en parte inculparon de rezos y actos moriegos a su marido y a su hermana Gracia, en vez de ser reconciliados volvieron todos a la cárcel. La situación debía ser ya insostenible para la familia y prueba de ello pudiera ser el que el único hijo de Juan y Ana, Juanico, marchó por estos años a Argel, donde su primo Juan Zafar desempeñaba un cargo importantísimo en el Gobierno. La Inquisición da noticia de ello en junio de 1580, diciendo que "fue por voluntad de su padre con 30.000 escudos que le dio y que triunfa en Argel con otro Rey". En 1581, posiblemente conocedor de parte de los infortunios de su familia, con la ayuda de un fraile el joven decide regresar a Zaragoza. Su decisión no pudo ser más equivocada, pues la Inquisición le llama y sufre duros interrogatorios sobre los motivos de su marcha, estancia y regreso de Argel. El joven, que rondaba los 20 años, ante las acusaciones de vivir a lo moro, con prácticas religiosas de la secta de Mahoma, etc., confiesa haber vivido como moro en Argel e incluso haber sido allí retajado; y afirma que ya ha olvidado su antigua religión y haberse convertido fielmente al cristianismo, pero la Inquisición zaragozana, en una carta a Madrid, recuerda que sus padres siguen presos y que él no satisfizo suficientemente su testificación, por lo que debe seguir en la cárcel ${ }^{16}$. Por estas mismas fechas están

16. A.H.N.M., Inquis., Libro 964, fols. 363, 396 y 479. 
siendo juzgados sus padres, sus dos tías maternas, María y Gracia, y sus tíos paternos, Jerónimo Zafar y Cándida Compañero. Tras verse sus procesos, se decide que las tres hermanas Navarro y su cuñada Cándida Compañero deben estar en prisión "a su costa" y pueda cumplirse "en casas particulares o en Monasterios zaragozanos". La caridad de sus hermanos de religión es muy dudosa pues se niegan a darles cobijo y también es cuestionable la de los religiosos cristianos viejos de monasterios y conventos que tampoco las acogen, aduciendo "ser muy importantes y peligrosas", en especial la más joven de ellas, Gracia Navarro. Esta situación es la que vive el clan de los Compañero-Navarro: todos ellos presos por el Santo Oficio y expectantes ante su futuro y el de sus jóvenes hijos, porque no debemos olvidar que de estos matrimonios jóvenes nació Juanico, hijo de Juan y Ana Navarro, que en estos momentos está en la cárcel, un hijo de Cándida Compañero y Jerónimo Zafar y dos niños cercanos a la adolescencia, hijos de la joven viuda Gracia Navarro, tenida por las autoridades inquisitoriales como peligrosa, porque estando presa en la cárcel zaragozana de la Aljafería, consciente de la soledad de sus pequeños hijos, pues todos los miembros de su familia están presos, huye saltando por una ventana y, con una pierna rota y malherida, llega a cobijarse en una cueva donde la encontraron y vuelve a la cárcel. Mientras, el joven Juanico Compañero espera con su tío Jerónimo Zafar el fallo de sus procesos, fallo que anuncia la relajación y muerte de ambos, pero que su tío sufrirá en estatua al morir en la cárcel, tras ser duramente torturado. Así vemos que el único nieto llamado Juanico, que conocieron sus abuelos, Miguel Navarro y Ana Ovex, tras cumplir su condena de cárcel, tomará parte en Zaragoza en el Auto de Fe del 6 abril de 1582, en el que los escritos inquisitoriales dicen "quedó en poder de los muchachos y otras gentes que le dieron cruel tormento y cuando iba camino de la hoguera murió apedreado por la muchedumbre, pero pertinente en su fe". Así moría el primer nieto de Miguel Navarro y Ana Ovex, mientras sus padres permanecían en la cárcel de Cuenca y sus tres tías en la de Logroño ${ }^{17}$.

Corría el año 1582, y ya habían desaparecido tres o cuatro varones de la familia, pues de Alonso de Almaguaque, esposo de María Navarro, sabemos que también fue acusado de participar en la negativa a dejar las armas los moriscos, tras el mandato real, de haberse reunido con otros moriscos principales en Borja en 1577 y de hospedar en su casa a Izquierdo, "planeador de los complots y amigo de Francia y de Argel"18. Desde esta fecha no hallo noticias sobre Alonso de Almaguaque, pero todo hace suponer que, dadas las acusaciones de implicado en "la preparación de posibles complots", su rebeldía a cumplir la orden del desarme y sus peligrosas amistades, fue enviado a galeras y nunca volvió. Desde luego, cuando se castiga a su mujer en el Auto de Fe de marzo de 1581, ya se le califica como viuda. Unos años después tendremos la última noticia sobre

17. A.H.N.M., Inquis., Libro 964, fol. 495 y Libro 965, fols. 144 y 396.

18. A.H.N.M., Inquis., Libro 964, fol. 72. y ss. 
el hijo varón del matrimonio Navarro Ovex, llamado como su padre Miguel Navarro y a quien sus padres nombraron heredero universal. Miguel Navarro tuvo una buena relación familiar con sus hermanas y cuñados, con los que participó en importantes negocios, pero también sufrió la persecución y castigos inquisitoriales, pues se le acusó de practicar costumbres y ritos musulmanes y tomó parte en el Auto de Fe de marzo de 1581. Fue condenado a cárcel perpetua y cuatro años en galeras. Desde esta fecha no he encontrado ninguna noticia sobre él y todo parece indicar que fue enviado a galeras y nunca regresó. A la misma conclusión llega A. Conte en su estudio sobre los moriscos de Huesca, con quienes, por conexiones familiares, participó en distintos negocios Miguel Navarro ${ }^{19}$.

En el Auto de Fe de marzo de 1581, las penas impuestas a las tres hermanas Navarro no fueron similares, pues mientras Ana y Gracia, acusadas de prácticas musulmanas y, lo que es más grave, la segunda de instruir a sus hijos en ellas, son castigadas a prisión perpetua, reclusión durante diez años en un monasterio y el pago de diez ducados, a su hermana María, acusada de guardar libros moriegos, se le condena sólo a cuatro años de prisión, dos recluida en un monasterio. Posiblemente a esto se deberá el que el 8 de enero de 1587 María Navarro expone al Santo Oficio que ya cumplió dos años de cárcel en Zaragoza y cuatro en la de Logroño, es decir, de cuatro años que debía estar recluida ha pasado ya seis, por lo que "ruega a su Ilma le aga la merced de quitarle la carcelería y darle licencia para ir a su casa con entera habilitación, como se acostumbra con los buenos penitentes", recordando a su vez lo mucho que ha perdido su hacienda en este tiempo, pero su petición no fue bien acogida, pues siguió junto a sus hermanas en la prisión de Logroño y con ellas estuvo hasta el final de sus días ${ }^{20}$.

Desde 1581 todos los miembros adultos de las familias formadas por los Navarro y Compañero están en la cárcel, en galeras o ya han desaparecido en éstas o en la hoguera. Los todavía vivos siguen presos en las cárceles inquisitoriales de Cuenca (Ana Navarro y Juan Compañero) o en la de Logroño (María y Gracia Navarro y su cuñada Cándida Compañero, cuyo pequeño hijo también ha muerto en este tiempo de cárcel). Sólo dos adolescentes, Miguel Enrique y Cándida Compañero Navarro, hijos de la joven viuda Gracia Navarro, debido a su corta edad, están fuera de ellas, viviendo en casas de cristianos viejos "para que les instruyan en la fe cristiana y olviden la enseñada por los suyos". Tras los profundos sufrimientos por las muertes de sus seres más queridos, comienzan para todos los castigados unas décadas de intensa actividad en su lucha por recuperar su libertad, pero las acusaciones sobre su intervención o planeamiento de complots y de amistad con Argel, Constantinopla y Francia continúan para Juan Compañero, y las referentes a las prácticas y costumbres moriegas, fidelidad y enseñanza de los preceptos coránicos y las ocultaciones para no acusar a otros moriscos de estas faltas se hacen cada día

19. A. CONTE, op. cit., p. 344.

20. A.H.N.M., Inquis., Libro 965, fol. 496. 
más persistentes para las mujeres Navarro y Compañero. Desde 1585, y con más intensidad desde 1587, se multiplican las cartas enviadas al Santo Oficio por estas egregias moriscas desde las cárceles. En ellas piden clemencia y permisos de salida para arreglar "sus haciendas y sus bienes harto disminuidos y perdidos por su ausencia" y con los que tienen que pagar su sustento en las cárceles o los de los niños Compañero Navarro en casas de particulares ${ }^{21}$. Los escritos de Juan Compañero dan lugar a cruzada correspondencia entre los tribunales de la Inquisición de Zaragoza, Cuenca y la Suprema desde Madrid. En ellos pide su libertad temporal o total y que se quiten los hábitos a él y a su esposa. También recogemos la noticia de que, tras dar en octubre de 15881.500 ducados o 12.000 reales de fianza, en diciembre se les han quitado los hábitos, pero siguen presos en Cuenca. Estas noticias de 1588 coinciden con otras mucho más tristes. Gracia y María Navarro y la única hermana de Juan Compañero, Cándida, siguen sufriendo los rigores de la cárcel de la Penitencia en Logroño. De ellas, la más delicada de salud y entristecida por la suerte de sus pequeños hijos, Miguel Enrique y Cándida, es Gracia, que escribe reiteradamente solicitando permiso del Santo Oficio para que sus hijos puedan estar junto a ella o en casas de cristianos viejos de Logroño "para tenerlos más cerca", pero sólo consigue cortas visitas de éstos ${ }^{22}$. Desde 1581 se había deteriorado la salud de esta joven morisca (apenas sobrepasaba los 30 años cuando comenzó su proceso), y por ello sus jóvenes hijos solicitan una y mil veces su libertad o sus cuidados, ofreciendo importantes sumas de dinero, pero sus angustiosas llamadas de atención no fueron oídas por la "incurable sordera" de los poderes y así, tras haber pasado por la cárcel inquisitorial de la Aljafería zaragozana, continuaba su castigo en la de Logroño, en cuya ciudad tomaría parte en el Auto de Fe celebrado el 21 de diciembre de 1588. La pena de esta egregia morisca está sustentada en una tríada de sufrimientos: en primer lugar el absoluto desamparo en que quedan sus hijos, pues todas las mujeres de su familia están presas y dos de ellas, su hermana y su cuñada, le acompañan en su camino hacia la muerte; en segundo lugar el temor muy fundado de que sus hijos, tras perder sus haciendas y requisados sus bienes, corran la misma suerte que ella y los suyos, y por último su "anunciado" y desgraciado fin, pues su relajación y muerte, junto a la de su hermana María y la de su cuñada Cándida Compañero Zafar, tendrá lugar, como hemos apuntado, en las vísperas de la Navidad de $1588^{23}$.

Estamos clausurando el año 1588 y ya han "desaparecido" por el rigor de los poderes seis miembros de la familia Navarro-Ovex y los cuatro que todavía viven siguen en el punto de mira de la Inquisición y del Estado. Así, Ana Navarro y su esposo permanecen en la cárcel de Cuenca, desde donde él solicita permiso para ir a Aragón, el cual se le concede en enero de 1589, tras pagar 2.000 du-

21. A.H.N.M., Inquis., Libro 328, fols. 369, 441.

22. A.H.N.M., Inquis., Libros 327, 328 y 329.

23. A.H.N.M., Inquis., Libro 989, fols. 395-459. 
cados "por la ocupación de sus hábitos y los de su mujer", y con la condición de que "no pueda salir destos reinos de su majestad" y se presente al Santo Oficio cuando se le ordene. Su "recobrada libertad" la ocupó en intentar poner al día sus negocios y su economía y ayudar a sus adolescentes sobrinos Miguel Enrique y Cándida, únicos nietos que siguen con vida de Miguel Navarro y Ana Ovex, aquellos niños que participaron en el bautismo forzoso de 1526.

\section{Miguel Enrique y CÁNdida Compañero NaVARro: Últimos Nietos de Miguel NaVARRo y ANA OveX}

Escritores del siglo XVII, como P. Aznar Cardona, M. Guadalajara y J. Bleda, dan noticias sobre un proyecto de reparto de España entre los principales moriscos y al referirse a "los reyezuelos aragoneses" señalan como tales a "Miguel Enrique Compañero y su esposa Esperanza Granada" ${ }^{24}$. No hay duda de que era vox populi entre las sociedades de cristianos nuevos y de cristianos viejos y entre los poderes dominantes la importancia de Miguel Enrique Compañero y de su liderazgo, heredado de su tío Juan. Él mismo conocía los riesgos que ello conllevaba, pues fue consciente de que la razón de su relajación y muerte y la de su joven esposa, además de todas las de tipo cultural, religioso, económico, etc., que habían "conducido" a sus familiares al castigo y la muerte, era fundamentalmente lo que ellos representaban, por lo que él mismo calificó su muerte como "una razón de Estado". Además, su estatus y consideración traspasaba nuestras fronteras, con redes de importantes amigos y miembros de su familia, como su primo Juan Zafar, que ocupó cargos destacados en lugares del poder turco, prioritariamente en Fez y Argel.

Sobre la triste vida y trágica muerte de Miguel Enrique Compañero y Esperanza Granada, su joven segunda esposa (su primera esposa fue Isabel de Almatar) di ya extensa noticia ${ }^{25}$, por lo que aquí daré solo un breve apunte de la misma, enlazándola con la de su hermana, Cándida Compañero Navarro. Ambos eran hijos de dos importantes jóvenes moriscos: Enrique Compañero Zafar y Gracia Navarro Ovex, casados en la iglesia de San Pablo de Zaragoza el 20 de junio de 1566, y cuyos hijos creemos que nacieron en 1568 y 1570-1571. Muy prontamente quedaron huérfanos de padre y su madre se encargó de los dos niños con la ayuda de su hermana Ana y su doblemente cuñado, Juan Compañero, el líder más respetado por la sociedad morisca aragonesa. En el za-

24. P. Aznar CARDOna, Expulsión justificada de los moriscos españoles, Huesca, Pedro Cavarte, 1612; Fr. M. Guadalajara, Memorable expulsión y iustissimo destierro de los moriscos de España, Pamplona, Parte II, 1613; J. BledA, Crónica de los moros de España, Valencia, 1618.

25. M.C. Ansón CAlvo, «Los últimos Reyezuelos Moriscos de Zaragoza», en E. Soria Mesa, J.J. Bravo Caro y J.M. Delgado BARrado (coords.), Las Elites en la Epoca Moderna: La Monarquía Española, Córdoba, 2009, vol. I, pp. 32-59. 
ragozano barrio de San Pablo sus padres y sus tíos poseían un buen número de casas, en una de las cuales, sita en el callizo del Peco, y una de las mejores, como se deduce de la valoración de los bienes de los moriscos hecha tras su expulsión ${ }^{26}$, vivieron Miguel Enrique y su hermana Cándida con su madre protegidos por su importante clan familiar, y pasando parte de su infancia, adolescencia y juventud entre Zaragoza y en su casa de la calle Herrerías en Huesca, de donde eran oriundos sus abuelos paternos y donde heredaron importantes propiedades que el joven Miguel Enrique amplió, llegando a estar considerados entre los moriscos más acaudalados e importantes de su tiempo.

Para Miguel Enrique y su hermana Cándida, nacidos en el seno de una "vieja" y admirada familia morisca, nada hacía presagiar que pudieran llegar a soportar las duras penalidades que sufrieron desde su más corta edad. Huérfanos desde muy niños de padre, inician una tristísima infancia, pues su joven madre, junto con sus hermanas Ana y María y sus cuñados Juan y Cándida Compañero y el marido de esta última, Jerónimo Zafar, comienzan desde 1575, cuando los dos niños contaban entre 5 y 7 años, a sufrir una dura y reiterada persecución inquisitorial, que también sufrieron sus familiares afincados en Huesca. Su madre y sus tías eran consideradas como mujeres muy ricas, guardianes de sus tradiciones y costumbres, poseedoras de muchos "Alcoranes y libros moriegos", que leían a sus hijos y criados en sus casas, cualidades que, como ya hemos comentado, harán que desde 1581 hasta su muerte la residencia habitual de ellas sean las cárceles inquisitoriales, lo que motivará la privación de la presencia femenina en las vidas de los niños Compañero-Navarro y el angustioso deseo de libertad de su madre, consciente de la situación de sus pequeños hijos residentes en casas de cristianos viejos, para instruirles en la religión cristiana y alejarlos de los suyos.

La constante desconfianza y persecución hacia los miembros de las familias Compañero-Navarro no es única. Los años que siguen a la rebelión de Las Alpujarras y otros eventos en la política exterior hacen que en España se respire una sensación de auténtica intranquilidad política, en la que va a tener un significado especial el papel de la minoría morisca y sus relaciones con quienes España considera sus enemigos. En círculos políticos y en instituciones del poder se habla de reuniones en las villas moriscas zaragozanas de Alfamén, Torrellas y Almonacid, en las que "treinta hombres estudian la oferta del gobernador de Bearn, M. de Ros, de invadir España, si los moriscos aragoneses le proveen de unos 10.000 ducados para los gastos". Estas noticias y otras similares, como el que 40.000 hombres de guerra se han ofrecido al príncipe de Bearn para la guerra contra España y el reparto de Aragón tras la posible victoria bearnesa y otras sobre posibles levantamientos, se suceden y en ellas se verán implicadas las familias moriscas más importantes de Aragón (Compañero, Navarro, Zaydejos, Zafar, Almaguaque, Monferriz, Albariel, Castellano,

26. M.C. ANSÓN y P. GAY, op. cit. 
etc.) y desfilar en los Autos de Fe a la madre y las tías de los niños M. Enrique y Cándida, y en el Auto de abril de 1582 verá el adolescente Miguel Enrique (tenía unos quince años), el apedreamiento, relajación y muerte de su primo más querido, Juan Compañero, cuando apenas sobrepasaba los 20 años de edad, mientras su madre y sus tías permanecen encarceladas. Las relaciones de causas inquisitoriales dan reiteradas noticias sobre los esfuerzos pecuniarios que inútilmente hizo Miguel Enrique para librar a su madre del hábito vergonzante y de la cárcel que sufre desde 1578, así como las inútiles peticiones de ella para ver a sus hijos, rogando los dejen en libertad pues "nada han pecado ni faltado a la fe", pero la Inquisición no escuchará a esta angustiada madre que, como hemos expresado, morirá relajada junto a otros familiares en diciembre de 1588. Un poco antes, desde 1587, encontramos a Miguel Enrique Compañero viviendo en Zaragoza y siendo ya desafortunado protagonista de problemas con la Inquisición. Así, en el Auto de Fe celebrado en Zaragoza el 8 de junio de 1587, cuando contaba 20 años, se le cita entre los reconciliados por prácticas y errores de la secta de Mahoma y su absolución, debida a haber sido instruido por sus padres a muy corta edad. En este mismo Auto, por las mismas causas, también será reconciliada su hermana Cándida de 17 años, es decir, que mientras la madre seguía presa en la cárcel de Logroño, sus hijos también "tomaban ya parte forzosa" en los actos inquisitoriales. Seis meses después, 21 de diciembre de 1588, serán relajadas en persona tres importantes mujeres viudas de su familia: su tía materna María, su tía paterna Cándida Compañero, que ya ha sufrido la muerte en las cárceles de su marido $(5, \mathrm{IV}, 1585)$ y de su hijo, y su propia madre, de 37 años, a quien se le acusa de no haber mostrado arrepentimiento durante sus años de cárcel, de practicar ritos y ceremonias de su secta, enseñarlas a sus hijos y criados y leerles sus libros moriegos, acusaciones que la rea, con una fortaleza ejemplar, confesó y ello le deparó, como ya señalamos, ser relajada en Logroño en 1588, junto a su hermana María y su cuñada ${ }^{27}$. En este mismo año 1588 Miguel Enrique Compañero fue nuevamente castigado por el Santo Oficio por vestir prendas prohibidas (ropa con bordados en oro y plata, no permitida a la minoría morisca), y por llevar armas y andar a caballo, acusaciones que confesó. Su castigo fue pagar las costas del juicio y 30 escudos "al Santo Oficio".

Tras la muerte de su madre y sus tías, sólo sus tíos Juan Compañero y su esposa Ana Navarro quedan a los hermanos Compañero, que contraerán matrimonio en los alrededores de 1590-1592. Miguel Enrique con Isabel Almatar del pueblo de Saviñán, de la que quedará pronto viudo con un niño llamado, como su padre, Miguel Enrique, y Cándida celebrará una suntuosa boda en su parroquia de San Pablo de Zaragoza, el 26 de enero de 1592, con el importantísimo morisco Diego de Rojas, residente en Valdepeñas y contador del marqués de Santa Cruz, de quien también quedó viuda. De ambos hermanos tracé mas ex-

27. A.H.N.M., Inquis., Libro 964, fols. 361-396, 430 y 479-495. Libro 965, fols. 92-98 y Libro 988, fols. 92-98 y Libro 834, fols. 487-489. 
tensamente sus vidas (ver notas 8 y 24) y aquí tan sólo recordaremos que los dos contrajeron segundos matrimonios con personas ricas e ilustres. Miguel Enrique con una muy joven prima de su mujer, de Épila, llamada Esperanza Granada, cuyo matrimonio vivió en su espaciosa casa de la calle del Peco, de la parroquia zaragozana de San Pablo. En esta misma iglesia su hermana contraerá su segundo matrimonio el 26 de enero de 1604 con un nobilísimo morisco andaluz, descendiente de la dinastía meriní, Alonso Muley Enríquez y Merín de Fez. No queda constancia de que Cándida tuviera descendencia, pero su hermano ya hemos apuntado que tuvo un hijo de su primer matrimonio, Miguel Enrique Compañero Almatar y del segundo, con Esperanza Granada, nacieron entre 1600 y 1607 tres hijos que sobrevivieron al matrimonio: Ana Francisca, Gabriel y María Lupercia, más dos niños que fallecieron a muy corta edad, todos ellos bautizados en la parroquia zaragozana de San Pablo. La vida de Miguel Enrique y Cándida continuó siendo dura y difícil, al igual que la de sus tíos Juan y Ana, y la de los principales moriscos aragoneses, pues todos seguían en el punto de mira de la Inquisición y del Estado, por lo que los apresamientos y condenas fueron in crescendo durante los últimos años del reinado del rey Prudente, tanto que según nuestras investigaciones, en el bienio 1595-1596, el 65\% de los juzgados en el tribunal inquisitorial zaragozano fueron moriscos y en el de 1597-1598 lo fueron el 82,15\%. Lo que Miguel Enrique Compañero veía era que sus familiares estaban presos en las cárceles y morían (su madre, sus tías, sus primos, etc.) o sirviendo en galeras y que la persecución era implacable, tanto que hoy podemos apuntar que en estos años la Inquisición llevó al 46,55\% de los reos moriscos a servir en las galeras reales ${ }^{28}$.

La llegada del nuevo siglo y del nuevo rey, "el cristianísimo" Felipe III de Castilla, no fue más halagüeña. De nuevo habrá acusaciones y castigos a Juan Compañero por su amistad con enemigos de España, proyectos de complots, cumplimientos religiosos del Islam o hasta por coger agua del término de la Aljafería para regar sus oliveras. Las de su esposa siguieron la tónica de las anteriores (costumbres y prácticas del Islam, lectura de libros moriegos, etc.) y ambos siguieron esperando los juicios sobre sus tristes vidas y conociendo las penalidades de sus sobrinos y sus familias, pues Miguel Enrique Compañero y su esposa Esperanza Granada, acusados por el Santo Oficio de practicar ritos de la secta de Mahoma, "xaedar" a los muertos, poseer libros coránicos y tener amistad con el turco, fueron enviados a las cárceles inquisitoriales, mientras sus pequeños hijos pasaban a ser tutelados por su abuelo, Jerónimo Granada y su tíos maternos en Épila, todos ellos también muy castigados por el Santo Oficio. Por otra parte, la hermana de Miguel Enrique, Cándida, a pesar de su recién estrenado segundo matrimonio, está presa por las mismas acusaciones de mora,

28. M.C. ANSÓN CALVO, «La actividad inquisitorial aragonesa en el reinado de Felipe II y su repercusión en los súbditos moriscos», en J. MARTínEZ MILLÁN (dir.), Europa dividida: La Monarquia Católica de Felipe II, Madrid, 1998, tomo III, pp. 11-36. 
seguidora de Mahoma, etc., con las que había sufrido los primeros castigos en su adolescencia. Corría el año 1606 y, tras aquellos breves interregnos que dieron lugar a que ambos hermanos se casaran y nacieran varios hijos de Miguel Enrique, de nuevo todos ellos están en las cárceles inquisitoriales, y en este año van a sufrir otro durísimo golpe familiar, pues tras el Auto de Fe de 26 de junio de 1606, tras casi treinta años de penalizaciones y castigos, moría su tío y tutor Juan Compañero, cuyo entierro se celebró en el convento zaragozano de San Francisco, perteneciente a la zona parroquial de San Pablo. En su testamento, salvo algunas dejas de bienes a distintos familiares, criados, pobres y un legado para huérfanas necesitadas, nombra como heredero universal a su sobrino Miguel Enrique, pero la vida de este mercader honorable y magnífico, como le califica en sus documentos el secretario del duque de Lerma, transcurrió sólo un breve tiempo "aparentemente" tranquila, pues de nuevo se le acusará a él y a su esposa de "moros convencidos, creyentes y practicantes" y de ser partícipes de complots o de tener amistades que derivaban en "males para el Estado", lo que motivó que, cuando "el reyezuelo morisco aragonés" contaba 40 años y su esposa tan sólo 25, fueran juzgados en el Auto Público de Fe celebrado en Zaragoza el 29 de octubre de 1608, condenados a "relaxar" al brazo seglar y a "ser quemados" en la hoguera, cuya sentencia consta que se ejecutó $^{29}$. No obstante, estos calificativos chocan con lo que se desprende de la lectura de su testamento, cuando "hallado preso y relaxado", expresa su última voluntad de ser enterrado en la iglesia y "se le hagan defunción, novena y cabo de año". También su esposa, Esperanza Granada, "pressa y relaxada por los Sres. Inquisidores y estando para morir", expresa sus deseos de ser enterrada en la iglesia, con defunción, novena y cabo de año y se celebren por su alma 300 misas rezadas, amén de donar importantes legados y dejas a los pobres de su linaje y a los de su parroquia zaragozana de San Pablo. Dado que Ana y Cándida siguen presas, deja a sus pequeños hijos al cuidado de su familia de Épila y de Gregorio de Andía, vicario de San Pablo que bautizó a sus hijos, casó a muchos Compañero y les ayudó a lo largo de sus tristes vidas. Así, el 29 de octubre de 1608 "desaparecieron" en la hoguera inquisitorial los últimos reyezuelos zaragozanos, dejando sin sus principales líderes a la comunidad morisca y huérfanos a sus pequeños hijos. Sólo quedan de los descendientes de aquellos niños, Miguel Navarro y Ana Ovex, bautizados forzosamente un siglo antes, una hija, Ana, una nieta, Cándida, presas por el Santo Oficio, y sus cuatro pequeños bisnietos, Miguel Enrique, Ana Francisca, Gabriel y María Lupercia, el mayor de 14 años y los otros tres tenían entre 1 y 8 años.

La vida de Ana Navarro y su sobrina Cándida se agravó en las cárceles ostensiblemente y sus procesos fueron muy duros. Al fin de unas vidas transcurridas mayoritariamente entre los muros de las cárceles inquisitoriales, en el Auto de Fe de noviembre de 1609 ambas serán condenadas a morir en la ho-

29. M.C. Ansón CAlvo, «Los últimos Reyezuelos Moriscos...». 
guera. Ana Navarro, la más acaudalada y respetada morisca zaragozana, tenía ya 70 cuando, acusada de nuevo por sus creencias moriegas y calificada de negativa convencida e impenitente relapsa, tras sufrir el tormento de la garrucha, le notifican su último castigo inquisitorial: la relajación y muerte. Llevaba presa en distintas cárceles inquisitoriales más de treinta años, tiempo en el que habían sido relajados su único hijo, sus hermanas y su marido. Dos años después conocerá el triste final de sus sobrinos, "los reyezuelos moriscos" Miguel Enrique Compañero y Esperanza Granada, relajados en el Auto de Fe de 1608. La única sobrina que le quedaba, Cándida, seguía con ella en la prisión inquisitorial zaragozana de la Aljafería, esperando también su condena de relajación en persona en el Auto de noviembre de 1609. La triste y larga vida de Ana Navarro mueve admiración y pena y es un claro ejemplo de resistencia física y anímica en una mujer cultivada, rica, poderosa y muy reconocida socialmente por pertenecer a una familia de la elite más reconocida y consagrada de la minoría morisca aragonesa, la de los Navarro-Ovex y después Compañero-Navarro, pero sus más graves pecados fueron precisamente los que ahora presentamos como cualidades. En su testamento, hecho tan sólo tres días antes de morir, expone que "presa y relajada por los Sres inquisidores y estando para morir y ser castigada por mis culpas y pecados" desea tener entierro, honras y misas por ella y por los suyos, por valor de 2.400 sueldos, en la parroquia zaragozana de San Pablo y, al igual que su marido, demuestra su generosidad con los necesitados, personas a su servicio, familiares y amigos, y deja herederos a los niños huérfanos de su sobrino relajado Miguel Enrique y a su sobrina Cándida, pero como ésta sigue presa esperando ser relajada, pide que administre sus bienes el vicario Gregorio de Andía, siempre presente en la vida de ella y de sus familiares. Con ella desaparecía la primera generación de los Navarro-Ovex, de la segunda sólo queda Cándida, esperando ser también relajada ${ }^{30}$.

En la relación de personas que la Inquisición aragonesa mandó salir en el Auto Público de Fe de 16 de noviembre de 1609, entre los relaxados por moros, encontramos con el número tres, tras su tía Ana Navarro, a Cándida Compañero. Se le inscribe como "morisca, de 37 años, mujer de D. Alonso Merin", y se recuerda que ya cuando contaba once años fue testificada de vivir como mora, que a los dieciocho años fue reconciliada en el Auto de Fe de junio de 1587, y de nuevo, por ayudar a amortajar a un familiar, en febrero de 1608. Las acusaciones son las mismas que en sus otros juicios, más la de un testigo que dijo haber recibido de Cándida 100 reales para que, cuando su hermano estaba preso por el Santo Oficio, no dijese que le había visto hacer ceremonias de moros. Aunque todo ello lo negó Cándida en tres audiencias, los testigos se ratificaron en ellas y se votó que, "como negativa convencida impenitente re-

30. A.H.N.M., Inquis., Libro 990, fol. 641 y otros. M.C. ANSÓN CALVO, «En el umbral de la muerte. Las últimas voluntades de la elite morisca zaragozana», Las elites en la España Moderna: La Monarquía Española, Córdoba, 2009, vol. 4, pp. 19-35. 
lapsa", sufriera tormento de la garrucha in caput alienum, y fuese admitida a relaxación con hábito y cárcel perpetua con confiscaciones de bienes en el Auto Público de 16 noviembre de 1609, y al final de todo el texto sobre ella se escribió: "executóse la relaxación". Ahora bien, éste es el texto formal de la causa, pero en el margen de éste hay una nota, escrita con letra pequeñísima y casi ilegible, que dice: "esta rea pidió audiencia en la mañana del Auto y confesó haber vivido como mora cuatro años y hecho ritos y ceremonias de moros con creencia y pertinacia después de su reconciliación, satisfizo a las testificaciones y vista en consulta se suspendió la execución de la sentencia de relaxación por agora como V. Sa. lo ordenó en el Auto de vista de esta ciudad". Esta nota me llevó a buscar exhaustivamente más datos en otros legajos y así pude encontrar una "oportuna" carta enviada de Madrid a la Inquisición de Aragón, notificando que se ha visto el proceso contra Cándida Compañero y se pide al tribunal zaragozano haga justicia pero con la concesión de que si la rea confesase en el tormento in caput alienum y satisfaciese, se volviese a votar y "siendo del parecer que se relaxase, la relaxía no se executase sin consultar a Madrid"31. Es decir, todo parece indicar que hubo algún hilo conductor que intentó evitar la relajación de Cándida Compañero. ¿Pesaría la importante personalidad de su egregio esposo? Lo cierto es que "alguien muy importante" debió de influir en Madrid, en los miembros del Tribunal inquisitorial zaragozano y, sobre todo, en el ánimo y obstinación de la rea, porque, tras sufrir tormento y seguir negando, en la mañana del Auto de 16 de noviembre de 1609, pidió audiencia y cambió su negación por la confesión de que, después de su reconciliación, vivió como mora durante cuatro años y practicó ceremonias de la secta de Mahoma, e incluso nombró a las personas con quien las había compartido. Posiblemente conocía el triste final de los miembros de su familia y sus más allegados, presos o ejecutados, por lo que su confesión, ahora, poco o nada podía ya influir en sus desgraciadas vidas. Así, pues, parece que hubo una "intervención" poderosa en el proceso de Cándida Compañero, que "aconsejó" su cambio de actitud y su confesión, que debió de ser la condición sine qua non para que el alto tribunal flexibilizase y hasta suspendiese la sentencia de relajación, de la que ya no encontré más noticias en los Libros de Relaciones de causas inquisitoriales, pero sí en la consulta de los Legajos, que recogen en parte correspondencia entre el Tribunal inquisitorial zaragozano y el Tribunal central de Madrid. Así, en una carta fechada en Madrid a 21 de mayo de 1610, firmada por M. Azevedo Valdés se dice: “aquí se ha visto el proceso de Cándida Compañero, presa en las cárceles y se devuelve con lo acordado en Madrid, rogando que en esta causa y en todas las de nuevos convertidos se proceda con la mayor brevedad". No encontré más noticias sobre este asunto, pero otros datos documentales nos llevan a deducir que Cándida Compañero se libró de

31. A.H.N.M., Inquis., Libro 989, fols. 49 y 395, Libro 990, fols. 488-490 y 641-642, Libro 991, fols. 23 a 25 y 94, Libro 332, fol. 192-194 y Libro 333, fol. 11. 
la relajación, pues se le cita en distintos documentos notariales hechos en los meses de junio y julio de 1610, es decir, poco después de publicarse el edicto de expulsión de los moriscos aragoneses, el 29 de mayo de $1610^{32}$. A este respecto es interesante señalar que en un documento notarial de 31 de julio de 1610 sobre un legado de 1.000 sueldos anuales hecho por su tío Juan Compañero, para casar huérfanas y parientes suyos, y del que nombró patronos a su mujer y a sus sobrinos Miguel Enrique y Cándida Compañero, ésta última señala "que sólo ella está viva, al haber muerto por la Inquisición sus tíos y su hermano" y "atendido que su Majestad manda que los moriscos convertidos salgamos de sus Reinos de España y que habiendo de cumplir lo mandado, no pudiendo estar en la presente ciudad para cumplir dicho legado y por no tener la vida cierta", y consciente de que por la expulsión pueden no quedar cristianos nuevos para aprovecharse del legado, expresa su voluntad de que, si no los hubiera, "dado que los hijos de mi hermano están ausentes de los reinos de España" (luego conocía que los únicos supervivientes de su familia habían salido con la expulsión), pase éste a mujeres y huérfanas pobres y da poderes a J. Gómez y a G. de Andía para la administración de dicho legado. Estas son las últimas noticias documentales sobre Cándida Compañero, noticias que me llevan a concluir que, muy enferma, casi ciega y muy limitada a sus 37 años, casi a la misma edad que murió en la hoguera su madre, Cándida se libró de ella y quizás pudo llegar a dirigir sus pasos hacia lejanas tierras. Su esposo, el destacado morisco descendiente de los Muley Merín de Fez, parece que ya había elegido ese camino cuando tuvo noticias ciertas del futuro de los suyos y de su próxima expulsión. Aznar Cardona, contemporáneo y presente en el evento de la expulsión, que conocía personalmente a los más destacados moriscos de Épila, nos dice que "Manuel Granada de Épila con su nieto Compañero, hijo de padres quemados, sacó más de 20.000 ducados y llegó a Francia con más de 17.000, vive hoy en Marsella y tiene consigo al fugitivo don Alonso Amuley, marido de la ciega, y al Doctor medico Calavera, su otro yerno, tan gran perro que nunca permitió quedarse entre los Christianos por más que muchos Cathólicos se lo persuadimos ${ }^{\prime 33}$. Salvando la equivocación de que el nombre del abuelo de los niños Compañero era Jerónimo y su tío era quien se llamaba Manuel, la noticia que ahora interesa es la que da sobre quien llama "Alonso Amuley", y califica como "fugitivo" y "marido de la ciega". Tras repetidas lecturas de los documentos y escritos sobre esta temática he llegado a deducir que éste "fugitivo y marido de la ciega" era el esposo de Cándida Compañero y ella es la calificada como "ciega". En documentos notariales estudiados que contribuyeron a trazar su vida, ninguno la señala como tal y constaba su firma. Sólo ahora, al final de su triste vida, encuentro alusiones contradictorias en la documentación. A veces en el momento de firmar una transacción, una venta,

32. A.H.P.Z., Not. Pablo Villanueva, Leg.106, año 1610.

33. P. Aznar CARdona, op. cit., II, 34. 
una deja, Cándida aludirá que no lo hace porque no sabe firmar, afirmación incierta, puesto que hasta 1608 son numerosos los documentos en los que estampa su firma y todas las noticias familiares y personales hacen deducir que era una persona culta, como todas las mujeres de su familia, y lejos de ser analfabeta. En otros documentos de 1609-1610, se dice que no firma porque no sabe y en otros se razona que no firma porque esta casi ciega y no ve. Es esta última afirmación sobre su ceguera la que me ha hecho deducir que el "fugitivo" Alonso Amuley, que cita Aznar como pariente "acogido" por el acaudalado e importante morisco de Épila, es el esposo de la ciega Cándida Compañero, que posiblemente perdió la vista en su largo y duro periplo de tinieblas por las cárceles inquisitoriales. Todo parece indicar que Alonso Muley Merín se acogió a la hospitalidad de su familia política y marchó con los Granada y los Calavera "acompañando" a los que quedaban de los Compañero, hacia tierras de África, también posiblemente con su esposa. Sería un acto de justicia poética este colofón sobre la egregia morisca Cándida Compañero Navarro.

\section{Los bisnietos de Miguel Navarro y Ana OveX: UN DURO CAMINAR HACIA EL EXILIO}

De aquellos pequeños niños, Miguel Navarro y Ana Ovex, que habían tenido una importante descendencia, sólo parece que no habían perecido por los castigos inquisitoriales su nieta Cándida Compañero (¿?) y sus pequeños bisnietos, nietos de su relajada hija Gracia e hijos de su nieto Miguel Enrique Compañero, quemado en la hoguera inquisitorial con su esposa en 1608, como ya hemos apuntado. Estos niños eran Miguel Enrique (portaba un nombre de su abuelo, como su padre), Gabriel, Ana Francisca y María Lupercia. Aznar Cardona nos dice que vio salir de Épila a uno de estos niños con su abuelo materno, formando parte de la caravana de moriscos expulsados en mayo de $1610^{34}$. Esta interesante noticia es curiosa, pues el matrimonio Compañero-Granada tenía tres hijos y otro más, Miguel Enrique, del primer matrimonio del padre. ¿Habían muerto los otros niños? Es extraño, porque sus padres y otros miembros de su familia, en documentos notariales hechos un año antes de la expulsión, citan a todos ellos. Quizás la cortísima edad de los tres más pequeños hizo que los "obviase" Aznar en su descripción.

La búsqueda de noticias sobre los bisnietos del matrimonio Navarro Ovex no ha terminado y en algún caso ha sido hasta afortunada. Así, sabemos que Miguel Enrique, Gabriel, Ana Francisca y María Lupercia, que salieron hacía el exilio desde el pueblo aragonés de Épila, parece que eligieron Túnez como su segunda patria. De los tres más pequeños hasta el momento no conozco la

34. Ibídem. 
suerte desde su marcha, pero sobre su hermano mayor, el tercer Miguel Enrique Compañero de la dinastía, Luis F. Bernabé y precisamente M. Epalza (a quien con las aportaciones aquí presentadas rendimos homenaje) nos dan algunas noticias de su presencia en tierras africanas ${ }^{35}$. Parece que Miguel Enrique Compañero, tras un viaje duro y agitado en el que le quitaron el dinero que llevaba y pasados muy distintos avatares, llegó a Túnez, donde debió de rehacer su vida apoyada en los recuerdos de su antigua patria. En esta ciudad residía en octubre de 1612, fecha en que se le cita como "proveniente de Zaragoza, del reino de Aragón", cuando hace una procura a Luis Zapata para que intente recobrar las cantidades de dinero robadas en su viaje. Posiblemente los miembros que quedaban de la estirpe de los Compañero-Navarro partieron de tierras aragonesas y llegaron a Marsella, donde sabemos que algunos moriscos, previendo su expulsión de España, habían llevado dinero e incluso comprado allí casas. Además, en Marsella residía el comerciante aragonés Jerónimo Enríquez, quien negociando con las autoridades francesas y otomanas preparó el viaje de los más acaudalados, entre los cuales cita Epalza a los Compañero. Desde Marsella, a cuya ciudad confirma Aznar Cardona que llegaron, debieron dirigir sus pasos a Túnez, ciudad que fue la más hospitalaria y en la que autoridades y pueblo brindaron a los moriscos exiliados mejor acogida que en otras próximas, como Argel. Posiblemente el joven Miguel Enrique Compañero Navarro ejerció allí de "patriarca" de sus pequeños hermanos y de otros miembros de su familia, se instaló en la zona del Barrio Alto de la ciudad, cerca de la Alcazaba, donde fijaron su residencia los moriscos más ricos y allí llevaron el recuerdo, los usos y costumbres de su verdadera patria, España, formando una sociedad en la que permanecen sus antiguas señas de identidad y en la que aquellos niños, últimos miembros de la saga Compañero-Navarro, intentaron olvidar las trágicas vidas de sus antepasados y las penalidades que ellos mismos soportaron desde su más tierna infancia, infortunios todos que nunca hubieran podido imaginar los primeros miembros de su destacada familia morisca zaragozana: sus bisabuelos Miguel Navarro y Ana Ovex, bautizados como cristianos en el invierno del año 1526.

\section{RESUMEN}

A partir de la pareja formada por Miguel Navarro y Ana Ovex, ricos moriscos zaragozanos, se reconstruye la terrible historia de esta familia aragonesa, emparentada con los más afamados apellidos moriscos de Aragón, como los

35. M. de EPAlZA, «Moriscos y andalusíes en Túnez durante el siglo XVII», Al-Andalus, XXIV, 2, 1969, pp. 249-327; Id., Los moriscos antes y después de la expulsión, Madrid, 1992 y «Trabajos actuales sobre la comunidad de moriscos refugiados en Túnez, desde el siglo XVII a nuestros días», Actas del Coloquio internacional sobre literatura aljamiada y morisca, Madrid, 1978, pp. 431, 437 y 462 y L.F. BERNABÉ, «La literatura en español de los moriscos en Túnez», IX Simposio Internacional de Mudejarismo, Teruel, 2002, pp. 449-464. 
Compañero o los Çafar. A través de cuatro generaciones asistimos al éxito económico y social de la familia y a su progresiva caída por la incesante persecución inquisitorial. El Santo Oficio acabará aniquilando a casi toda la familia, de la que sólo se salvarán los bisnietos de los primeros al salir expulsados en 1610.

Palabras clave: Moriscos, elite, Aragón, Zaragoza, Inquisición, persecución.

\begin{abstract}
From the marriage between Miguel Navarro and Ana Ovex, rich Moriscos from Zaragoza, the history of this Aragonese family is reconstructed. Their family relations extend to some of the best known morisco names in Aragon, such as the Compañero or Çafar. Through four generations, we witness the economic and social rise of the family and its progressive annihilation due to inquisitorial persecution. The Holy Inquisition will end the life of most of the family members, with only some of the grandchildren surviving when expelled from Spain in 1610.
\end{abstract}

Key words: Moriscos, elite, Aragon, Inquisition, persecution. 